\title{
側方流動による地盤変位を受ける 埋設鋼管の大変形挙動
}

\author{
佐藤清 1 ・松本真明 2 ・高田至郎 3 ・ 小川安雄 4 \\ 1正会員 工修 （株）大林組 技術研究所（テ204-8558 東京都清瀬市下清戸4-640） \\ 2正会員 博(工） 住友金属工業（株） エネルギーエンジニアリング事業部 \\ （テ104-6111 東京都中央区晴海1-8-11） \\ 3フェロー 工博 神戸大学教授 工学部建設学科（T657-8501 神戸市灘区六甲台町1-1） \\ 4 正会員 博（工）大阪ガス（株）技術部 土木建築技術チーム（テ 541-0046 大阪市中央区平野町 4-1-2）
}

\begin{abstract}
地震時の地盤液状化に伴う側方流動が埋設配管に与える影響を把握するために, 遠心模型振動実験およ び FEM シェル解析手法による数值シミュレーションを実施した. 遠心重力場 $30 \mathrm{~g}$ での模型実験はケーソン 護岸とその背後地盤によって構成され, 加振時の背後地盤液状化と護岸変位により側方流動を発生させた. 配管構造物は外径 $600 \mathrm{~mm}$ ，肉厚 $15 \mathrm{~mm}$ の高圧ガス導管を対象とし，90度曲部を含む構造とした．実験の結果， 模型管に塑性変形が生じるまでの変位が生じ, 地盤変位と管変位の関係や管の変形形状などが把握できた. さらに, 数值シミュレーションでは, 実験による模型管の変形を良好に再現でき, 手法の妥当性が確認さ れた.
\end{abstract}

Key Words : liquefaction, lateral displacement, underground pipe, centrifuge model test, large deformation, FEM analysis, soil spring

\section{1. はじめに}

埋設管の地震時被害には継手部の破損や抜け出し, 管本体の折損などが考えられるが, これらの被害は 周辺地盤の残留変位と密接に関係している ${ }^{1), 2)}$. 埋設 管の耐震性に最も影響する外的要因は地盤の大規模 変状であると考えることができ ${ }^{3)}$, 大規模な地盤変 状を受けたときの埋設管の被害メカニズムを明らか にし, 耐震性評価手法を確立することは重要な課題 の一つである.

埋設管に被害を与える大規模地盤変状の一つに, 地盤の液状化に伴う側方流動を挙げることができる. 側方流動は濱田 ${ }^{4)}$ や石原 ${ }^{5)}$ らの研究によりメカ二 ズムが理解され，傾斜地盤あるいは護岸背後地盤に おいて発生することが明らかになっている. また構 造物への側方流動の影響は, 各種設計指針類 ${ }^{6) \sim 8)}$ に おいて基礎構造物への水平力, 地盤の水平変位分布 といった形で設計に導入されている.

わが国では臨海部など護岸近傍にガス供給システ ムや上下水道施設等が配置されることが少なくない ため, 埋設管の耐震性評価においても, 側方流動に よる地盤変状の影響を無視することはできない. ガ 又導管の場合, 通常, 地表から1〜2m の深さに埋設
されるため, 埋設位置が地下水位面より上になる例 がある.このようなケースで下部層の液状化による 側方流動が発生した場合, 液状化層の流動量に応じ た変位が上部非液状化層にも生じ，埋設管に影響を 及ぼす．また，下部層が液状化することにより，上 部層の地盤バネは下部層が液状化しない場合よりも 低減することが示されており ${ }^{9)}$, 側方流動による地 盤変位を受けた埋設管の挙動は, 液状化と無関係に 地盤変位が生じた場合とは異なったものとして考え る必要がある.

側方流動に関するこれまでの実験的研究には，発 生メカニズムの把握 ${ }^{10)}$ 13) , 地盤変形量あるいは流

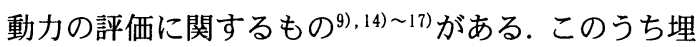
設管路の挙動を対象としたものでは, 液状化地盤中 の埋設管路を鈶直に引き上げ，液状化時の地盤拘束 力を求めた実験 ${ }^{17)}$ や, 護岸背後地盤における側方流 動から，管周辺の地盤拘束力を求めた実験9)がある. ただし，実測されている $3 \sim 4 \mathrm{~m}$ 程度の地盤変位によ り, 埋設管の大変形挙動や破壊メカニズムを直接再 現した実験例はない.

一方，埋設管の解析手法としては主に埋設管をは り要素, 地盤をばね要素でモデル化したはり解析手 法が用いられており, 地盤の変形量が小さい範囲で 


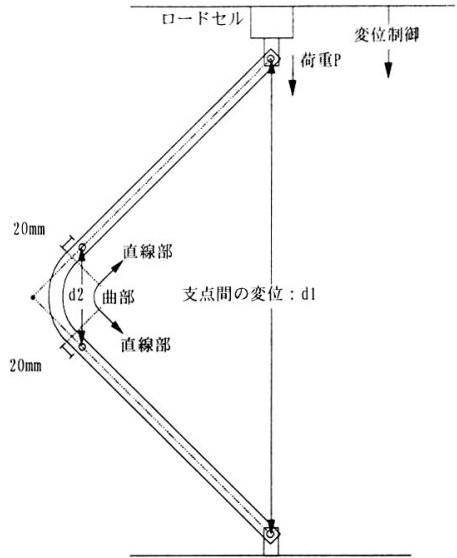

図-1 模型管の曲げ試験装置

は実験との整合性が確認されている(8) 20). しかし, はり解析手法は管の断面偏平, 座屈変形などの非線 形挙動を再現できないという適用限界がある.その ため, 液状化に伴う側方流動のように大きな地盤変 状が埋設管に作用する場合は埋設管の座屈現象を含 んだ大変形挙動を精緻に解析する手法が必要である. この場合, 埋設管をシェル要素, 地盤をばね要素で モデル化したシェル解析手法が考えられ，いくつか の解析 ${ }^{21}{ }^{2}{ }^{22)}$ が試みられているが, 実験結果との比較 による解析手法の妥当性について十分な検証はなさ れていない

本研究では以上のような背景から, 地下水位面の 上部に管路が埋設されている状況を想定し，(1)遠心 模型振動実験により，下部層の液状化に伴って数 $\mathrm{m}$ レベルの側方流動が生じた場合の埋設管の変形特性 を直接再現し，(2)実験結果を前述の大変形領域での 数值解析手法による計算結果と照合し，解析手法の 妥当性を確認した.

\section{2. 縮小模型管の検討}

\section{（1）模型管の作製}

実験に用いる模型管のサイズは，管の製造限界， 遠心模型振動実験に用いる土槽のサイズによる制約 を考慮して， $600 \mathrm{~A}$ 実規模管を1/30に縮小した外径 $20 \mathrm{~mm}$ ，管厚 $0.5 \mathrm{~mm}$ とした. 実験では $63 \mathrm{~cm}$ の直管部と $90^{\circ}$ 曲管部 (曲げ半径3DR) を有する L 字型の模型管を 製作し, 使用した.この模型管は内径 $19 \mathrm{~mm}$, 管厚 $1.5 \mathrm{~mm}$ の機械構造用炭素鋼管（STKM11A）を機械切削により 管厚を $0.5 \mathrm{~mm}$ の直管に加工したのち冷間曲げ加工し たものである。この加工による製作精度は，直管部 は外径が最大 $1.6 \%$ ，管厚が最大 $0.3 \%$ ，曲管部は外径 が最大 $3.8 \%$ ，管厚が最大 $0.5 \%$ あった。

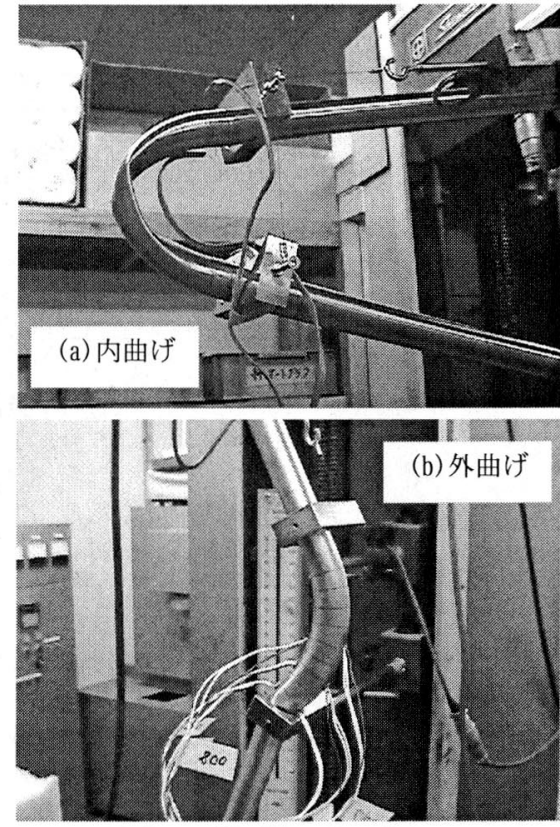

写真-1 模型管の変形状況

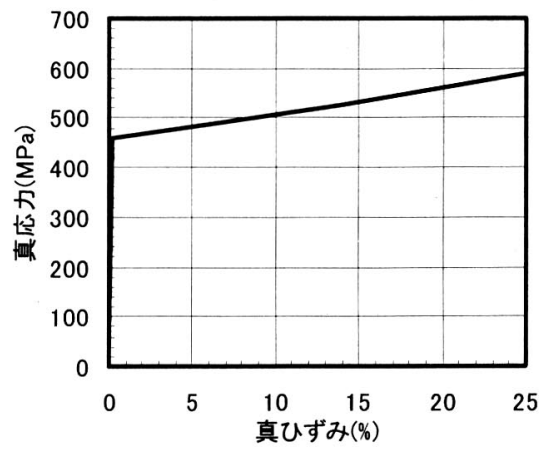

図-2 模型管の曲げ試験装置

\section{（2）縮小模型管の変形挙動}

本研究では縮小模型管 (実規模管の 1/30)によっ て大規模地盤変状による埋設管の変形を再現するこ とと, その結果を用いて数值解析手法を検証するこ とを目的としている.よって，遠心模型振動実験に 使用する縮小模型管の基本的な変形性状が実規模管 と同等であることと, その挙動が数值解析によって 精度良く再現できることを確認しておく必要がある そこで，曲管を含む縮小模型管 (管径 $20 \mathrm{~mm}$ ) の曲げ試 験と, その結果を対象とした FEM 解析を実施した.

縮小模型管曲げ試験の試験概要を図-1に示す．試 験は $20 \mathrm{~A} の 90^{\circ} \times 3 \mathrm{DR}$ 曲管の内曲げ変形と外曲げ変形 の 2 ケースについて実施した，内曲げ，外曲げにお ける変形状況を写真-1 に示す. 既往の研究 ${ }^{23)}$ では, 実管曲げ試験により，内曲げでは曲管中央部付近で 断面偏平による変形が進行するのに対して, 外曲げ 

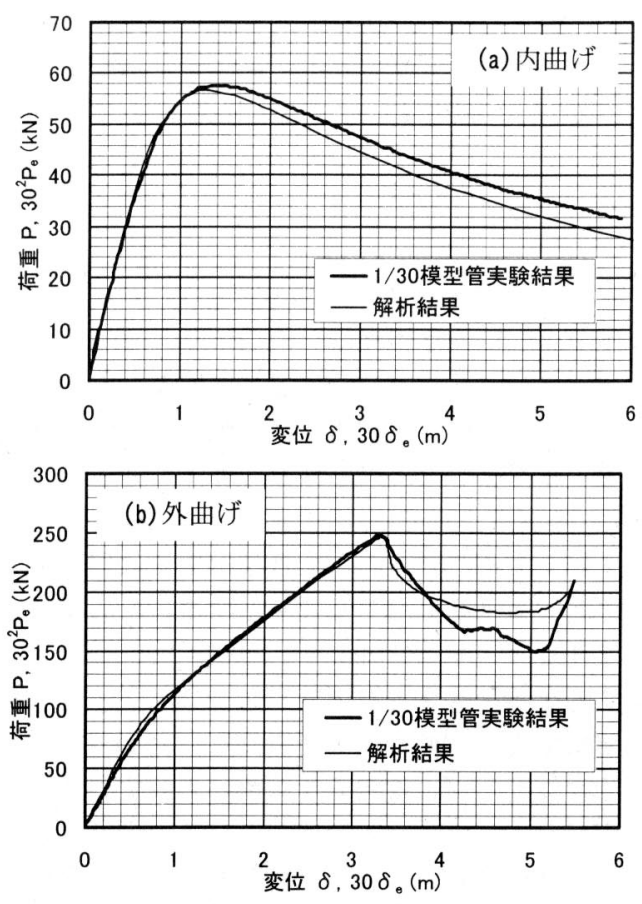

図-3 荷重と変位の関倸

では曲管の管端付近の直管部で座屈変形が発生する ことが明らかにされており, 縮小模型管の変形挙動 は，これらの特性を再現できている。 また，図-2 は 縮小模型管の応力〜ひずみ特性を示しており, 模型 管から採取した試験片による実測結果を元にバイリ ニアでモデル化している.この応力〜ひずみ特性は, 実管とほぼ同等の特性を示していることから ${ }^{23)}$, 模 型管の変形特性に以下の (1a)〜 (1b) に示す相似則を 適用して，幾何的相似率に応じた変換を行うことに より，実管の変形挙動として扱うこととする.

$$
\begin{aligned}
\mathrm{P} & =\mathrm{N}^{2} \cdot \mathrm{Pe} \\
\delta & =\mathrm{N} \cdot \delta \mathrm{e} \\
\mathrm{M} & =\mathrm{N}^{3} \cdot \mathrm{Me} \\
\omega & =\omega \mathrm{e}
\end{aligned}
$$

P ：実規模モデルの載荷点の荷重

$\mathrm{Pe} \quad: 1 / \mathrm{N}$ モデルの載荷点の荷重

$\delta \quad:$ 実規模モデルの載荷点の変位量

$\delta \mathrm{e} \quad: 1 / \mathrm{N}$ モデルの載荷点の変位量

M : 実規模モデルに生じるモーメント

Me $\quad: 1 / \mathrm{N}$ モデルに生じるモーメント

$\omega \quad:$ 実規模モデルに生じる曲げ角度

$\omega \mathrm{e} ： 1 / \mathrm{N}$ モデルに生じる曲げ角度

$\mathrm{N}$ ：実規模曲管と試験体曲管の寸法比

次に, 相似則によって縮小模型管曲げ試験の結果 を実規模に換算し，これを対象として FEM 解析を実 施した. 既往の研究 ${ }^{23)}$ では, FEM 解析が実管の大変 形曲げ試験結果を精度良く再現できることが示され

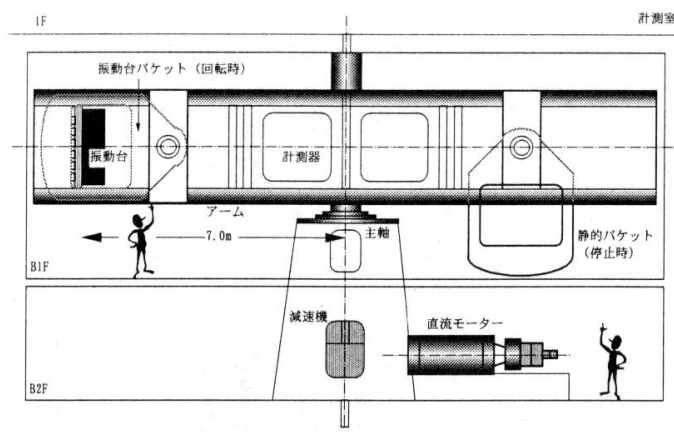

図-4＼cjkstart遠心模型実験装置

\begin{tabular}{|c|c|c|c|}
\hline 装置 & & 項目 & 仕様 \\
\hline \multirow{8}{*}{$\begin{array}{l}\text { 回転装置 } \\
\text { 他 }\end{array}$} & \multicolumn{2}{|c|}{ 最大回転半径 } & $7.01 \mathrm{~m}$ \\
\hline & \multicolumn{2}{|l|}{ 搭載容量 } & $700 \mathrm{t} * \mathrm{~g}$ \\
\hline & \multirow{2}{*}{ 搭載質量 } & 静的バケット & $7 \mathrm{t}$ \\
\hline & & 振動台バケット & $3 \mathrm{t}$ \\
\hline & \multirow{2}{*}{ 搭載面積 } & 静的バケット & $\mathrm{L} 2.2 \mathrm{~m} \times \mathrm{W} 2.2 \mathrm{~m}$ \\
\hline & & 振動台バケット & $\mathrm{L} 2.2 \mathrm{~m} \times W 1.07 \mathrm{~m}$ \\
\hline & \multicolumn{2}{|l|}{ 載荷高さ } & $2.5 \mathrm{~m}$ \\
\hline & \multicolumn{2}{|c|}{ バケット数 } & 静的, 動的各 1 \\
\hline \multirow{2}{*}{ 振動台 } & \multicolumn{2}{|c|}{ 最大加振加速度 } & $50 \mathrm{~g}$ \\
\hline & \multicolumn{2}{|c|}{ 最大加振力 } & $1200 \mathrm{kN}$ \\
\hline
\end{tabular}

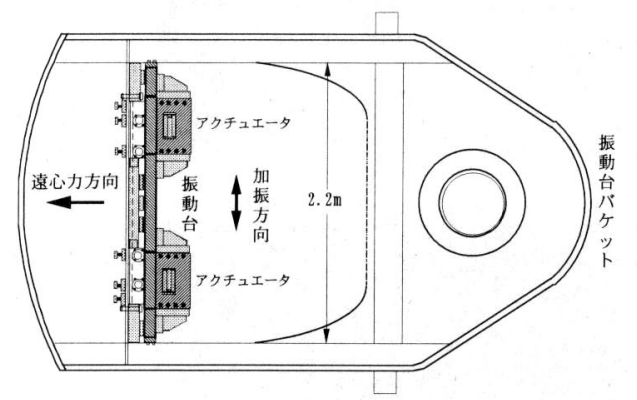

図-5 振動台

表-1＼cjkstart遠心模型実験装置の仕様

ている. 今回は解析コード ABAQUS（汎用 FEM 解析プ ログラム） ${ }^{24)}$ を使用して FEM シェル解析を行った. 管のモデル化には, 縮小模型管の実測值を相似則に 従って 30 倍した值を用いた. 解析は材料非線形と幾 何学的非線形を考慮し, 図-2 に示す応力〜ひずみ特 性值を使用した. 幾何学的非線形における応力とひ ずみは ABAQUS が標準として採用しているものを用 いており, 応力は真応力, ひずみは変形速度の積分 として定義されるひずみを使用した. ABAQUS は構造 解析によく用いられ ${ }^{25)}$, 各種の汎用コードとの比較 においても精度よく解析できることが報告されてい る ${ }^{26)}$. 解析結果の比較を図-3 に示す. 内曲げ, 外曲 げともに解析結果と試験結果は大変形領域に至るま で良く一致しており, 本解析が縮小模型管の基本的 な変形特性を精度良く再現できることが確認できた. 以上より, 縮小模型管によって埋設管の変形を再 

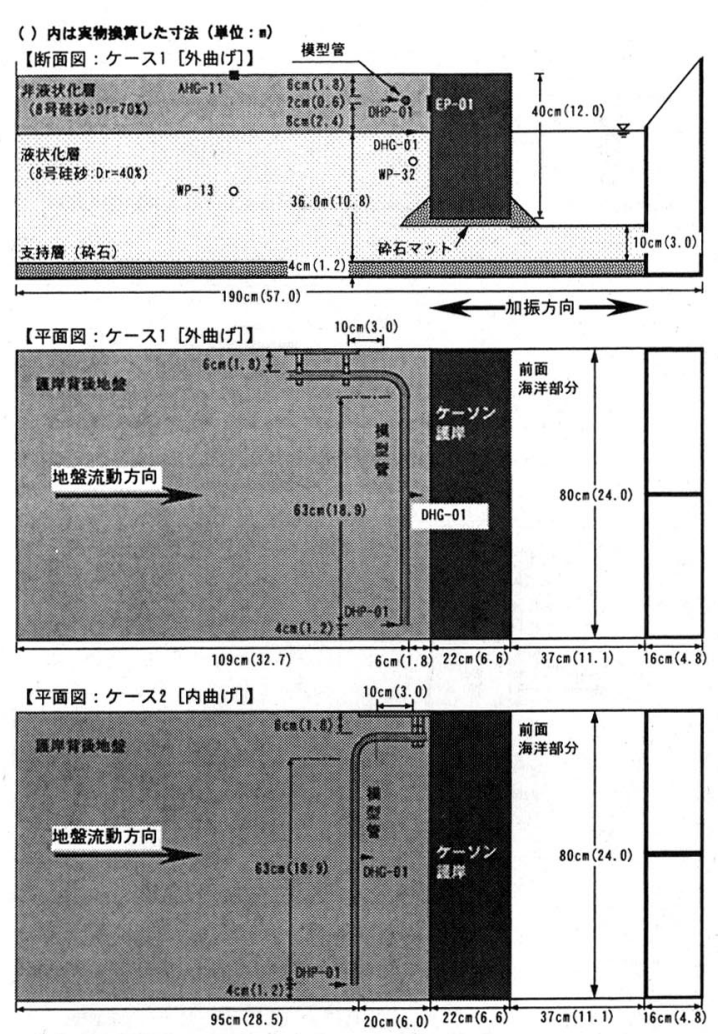

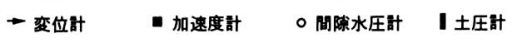

図-6 実験模型と計器配置

表-2 8 号硅砂の物理諸量

\begin{tabular}{l|l|ll|c}
\hline 土粒子密度 $\mathrm{Gs}\left(\mathrm{t} / \mathrm{m}^{3}\right)$ & 2.650 & 最大粒径 $\mathrm{D}_{\max }(\mathrm{mm})$ & 0.25 \\
\hline 最大間隙比 $\mathrm{e}_{\max }$ & 1.403 & 50 \%粒径 $\mathrm{D}_{50}(\mathrm{~mm})$ & 0.13 \\
\hline 最小間隙比 $\mathrm{e}_{\min }$ & 0.705 & 細粒分含有率 $\mathrm{Fc}(\%)$ & $14.3 \%$ \\
\hline
\end{tabular}

表-3 模型地盤の諸元

\begin{tabular}{l|c|c|c|c}
\hline \multicolumn{1}{c|}{ 項目 } & $\begin{array}{c}\text { 密度 } \\
\left(\mathrm{i} / \mathrm{m}^{3}\right)\end{array}$ & $\begin{array}{c}\text { 相対密 } \\
\text { 度 }(\%)\end{array}$ & 間隙比 & $\begin{array}{c}\text { 透水係数 } \\
(\mathrm{m} / \mathrm{s})\end{array}$ \\
\hline \hline 上部非液状化層 & 1.38 (乾燥) & 70 & 0.92 & - \\
\hline 下部液状化層 & 1.78 (飽和) & 40 & 1.22 & $8.1 \times 10^{-4}$ \\
\hline ケーソン護岸 & 2.16 & - & - & - \\
\hline
\end{tabular}

※）透水係数は実地盤に換算した值

現することと, その結果を用いて数值解析手法の検 証を行うことの妥当性が確認できた.

\section{3. 遠心模型振動実験の概要}

\section{（1）実験装置}

実験に用いた遠心模型実験装置は，遠心重力を発 生させる回転装置（図-4）と地震動を再現する振動 台（図-5）で構成される. 回転装置と振動台の仕様 を表-1に示す。振動台の搭載面積は長さ $2.2 \mathrm{~m}$, 幅 $1.07 \mathrm{~m}$ であり, 今回の実験ではこの振動台テーブル
全面を利用している. 加振方向は水平一方向で, 加 振力は電気油圧式アクチュエータにより制御する. 計測装置は, 回転装置内に設置されたオンボードコ ンピュータ制御のアンプ及び $\mathrm{A} / \mathrm{D}$ 変換装置と伝送部 及び地上にある記録部で構成される.

\section{（2）実験模型}

前述のように, 本実験は可能な限り大きな側方流 動を発生させ，埋設管を塑性変形させることを目標 とした，液状化に伴う地盤の側方流動は，傾斜地形 で発生するタイプと護岸の移動に伴って発生する夕 イプに分類されるが, 今回の実験では護岸タイプの 模型を作製することとした．模型実験で傾斜地形夕 イプの側方流動を再現する場合，再現できる側方流 動量は地表面勾配, 液状化層厚, 地盤密度などの他, 使用する土槽の大きさなどにも依存する ${ }^{11)}$. そのた め, 使用できる土槽や治具を考慮し, 今回目標とし た実物換算で3〜 4m 規模の側方流動を発生させるに は, 護岸タイプとした方が適していると判断した. 護岸背後地盤における側方流動の発生量は, 護岸の 高さに依存するが, 既往の地震事例では, 背後およ び基礎地盤がいずれも緩い砂質土の場合, 重力式護 岸ではレベル2地震動に対して護岸高さの20４0\%の 水平変位が生じた例が報告されている ${ }^{27)}$. 今回の模 型実験では，実物換算 $3 \sim 4 \mathrm{~m}$ 程度の側方流動量を得 るための護岸天端の目標移動量を $5 \mathrm{~m}$ 程度と考え, 文 献27)の例を元に, 護岸高さを実物換算で $12 \mathrm{~m}$ とした. 埋設する模型管は高圧ガス導管のうち大口径となる, 外径 $600 \mathrm{~mm}$, 肉厚 $15 \mathrm{~mm}$ のガス導管を対象とした. 遠 心重力場は, 縮小模型の製作精度を考慮して $30 \mathrm{~g}$ (模 型縮小率1/30）に設定した.

ここから実験模型について説明する. 文中の寸法 等は模型寸法を示し, 必要に応じて()内に実物換算 值を示す．図-6に実験模型の断面図および平面図を 示す．使用土槽は，内寸法で長さ $190 \mathrm{~cm} \times$ 幅 $80 \mathrm{~cm} \times$ 高 さ $60 \mathrm{~cm}$ の鋼製剛土槽である. 模型はケーソン護岸, 上部非液状化層と下部液状化層による護岸背後地盤, 上部非液状化層の埋設管（以後, 模型管と呼ぶ）に よって構成される. 地下水位面は $\mathrm{GL}-16 \mathrm{~cm}(4.8 \mathrm{~m})$ である. ケーソン護岸はモルタル製で高さ $40 \mathrm{~cm}(12 \mathrm{~m})$ ， 幅 $22 \mathrm{~cm}(6.6 \mathrm{~m})$ とし，土槽側壁との間は摩擦低減のた め, $5 \mathrm{~mm}$ の隙間を設けてグリースを充填した. また, ケーソン直下には直径 $5 \sim 10 \mathrm{~mm}$ の砕石を $2 \mathrm{~cm}(0.6 \mathrm{~m})$ の厚さで敷き, ケーソン設置時の安定性を高めた. 厚さ $16 \mathrm{~cm}(4.8 \mathrm{~m})$ の上部非液状化層は 8 号硅砂を相対 密度70\%に調整し, 下部液状化層も8号硅砂を使用し, 相対密度40\%になるよう調整した. 背後地盤は貯砂夕 ンクに貯めた硅砂をクレーンで吊り, 直径 $15 \mathrm{~cm}$ のホ 

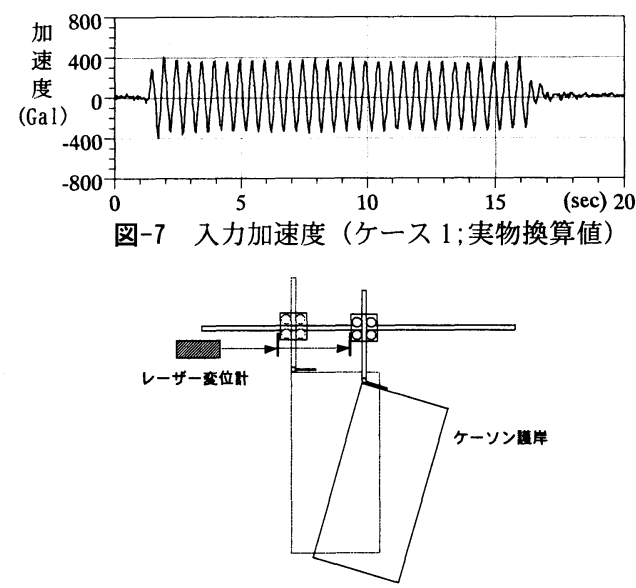

図-8 変位計測治具
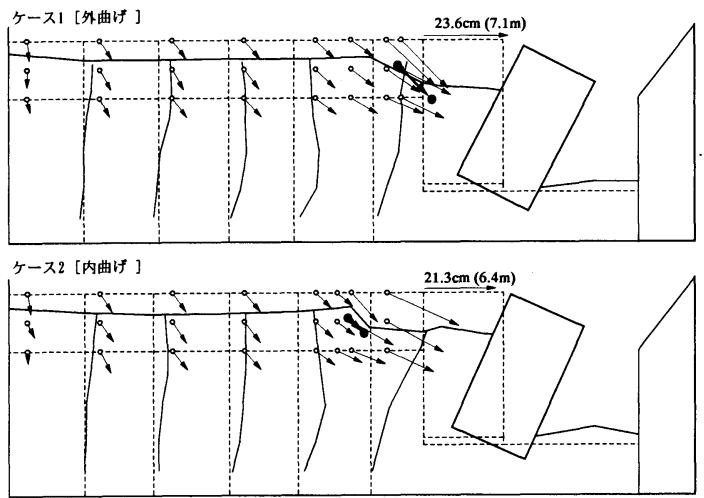

図-9 模型の最終変形断面

一スの先から土槽内に空中落下させることにより作 製した. ホースの先には鋼製の網を取り付けており, メッシュサイズと落下高さを変えることで出来上が り密度を調節した. 今回は, $50 \mathrm{~cm}$ 四方の容器内に模 型地盤を試作し，目標密度70\%および40\%を再現する ためのメッシュサイズと落下高さを決定した. 密度 は投入した砂の重量と投入部分の容積によって確認 した. 地下水には脱気水を用いた. 室内土質実験か ら求めた模型地盤の透水係数は $2.7 \times 10^{-5} \mathrm{~m} / \mathrm{s}$ であり, 実地盤に換算すると $8.1 \times 10^{-4} \mathrm{~m} / \mathrm{s}$ に相当する. この值 は, 中粒砂 $\left(\mathrm{D}_{20}=0.5 \mathrm{~mm}\right.$ 程度) に相当し, 液状化の可 能性があると判断される範囲内である ${ }^{28)}$. 表-2に 8 号硅砂の物理諸量, 表-3に模型地盤の諸元を示す.

模型管は上部非液状化層の土被り $6 \mathrm{~cm}(1.8 \mathrm{~m})$ の深 さに埋設し， $63 \mathrm{~cm}$ の直管部が地盤流動方向に直交す るように配置した，また，図-6に示すように，曲管 部から $10 \mathrm{~cm}$ 離れた位置で, アルミ製治具により模型 管を土槽に固定した. 固定位㯰を曲管部から $10 \mathrm{~cm}$ 離 したのは, 治具が曲管部の変形に影響しないように するためである. 治具と模型管の固定部は, 加振後 も回転やずれが無いことを確認している．模型管内
部は中空とし, シリコーンにより端部に薄く蓋をし て砂と水の浸入を防いだ. 模型管の配置は, 地盤流 動により曲管部が 90 度より開く方向に変形する [外 曲げ] と, 閉じる方向に変形する [内曲げ $]$ とした. 実 験は, 護岸から模型管埋設位置までの距離と入力加 度をパラメータとした4ケースの他, 模型管を埋設し ていない状態での実験を実施した. 本報では基本と なる2ケース, ケース 1 [外曲げ], ケース 2 [内曲げ] について報告する.

\section{（3）加振および計測方法}

加振は $60 \mathrm{~Hz}(2 \mathrm{~Hz}) 30$ 波の正弦波とし, 振幅は $12.2 \mathrm{~g}$ (400gal）を目標とした（図-7). 各ケースの最大振 幅はケース 1 が $12.3 \mathrm{~g}(403 \mathrm{gal})$, ケース 2 が $13.5 \mathrm{~g}(442 \mathrm{ga} \mathrm{l})$ であった. 計測項目は護岸・模型管の 水平変位, 地盤の水平変位および沈下, 加速度, 間 隙水圧, 護岸の壁面土圧などとした. 図-6に主な計 器配置を示す. 護岸および地盤の水平変位は非接触 のレーザー式変位計により計測した.レーザー光の ターゲット板は, 土槽に固定されたレール上を地盤 の変位方向に動くよう設置した滑車に取り付け, 滑 車と護岸天端をヒンジ結合することによって, 護岸 の水平成分のみを計測できるようにした (図-8). 模 型管端部の水平変位はレーザー式変位計による計測 が困難なため, ワイヤー式変位計を用いて計測した.

\section{4. 実験結果の考察}

\section{（1）護岸および地盤の残留変形}

ここから実験結果について説明する. 文中の寸法 等は全て実物換算值を示す.

図-9は模型の最終変形断面を示しており, 点線が 初期状態, 実線が実験終了後の状態である. 黒丸は 模型管端部の位置を示す. 図より, 護岸が大きく海 側へ変位し, 背後地盤が側方流動した様子がわかる. ただし, 図に示す護岸の変位は実験終了後に実測し た結果なので, 遠心力除荷時の地盤拘束圧の低下に よって進行した変位も含まれている. 加振直後の護 岸天端の水平変位は図中に矢印および変位量（ケー ス $1: 7.1 \mathrm{~m}$, ケース $2: 6.4 \mathrm{~m})$ で示した. なお, 水平 変位は護岸高さの50\%以上に達している.

非液状化層のうち模型管前面側では, 護岸の移動 に伴い，地盤が崩れるように変状している，模型管 背面側の地盤は管により流動が妨げられ，その結果 大きな土圧が発生し, 管に大きな塑性変形が生じた.

\section{（2）護岸背後地盤の液状化と側方流動}

図-10，11にケース1における背後地盤の過㮃間隙 


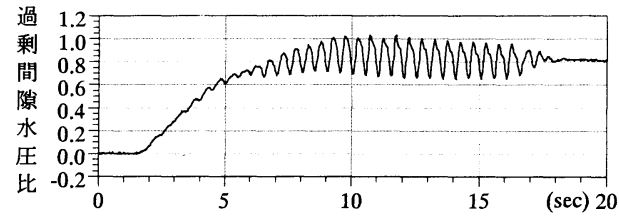

図-10 過剩間隙水圧比（ケース 1:WP-13）

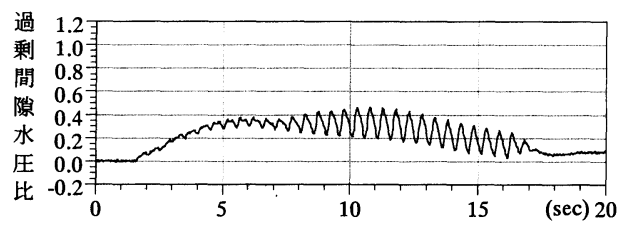

図-11 過剩間隙水圧比（ケース 1:WP-32）

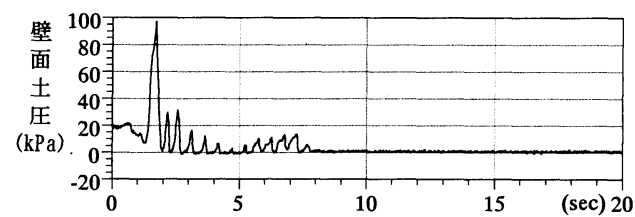

図-12 壁面土圧（ケース 1: EP-01）
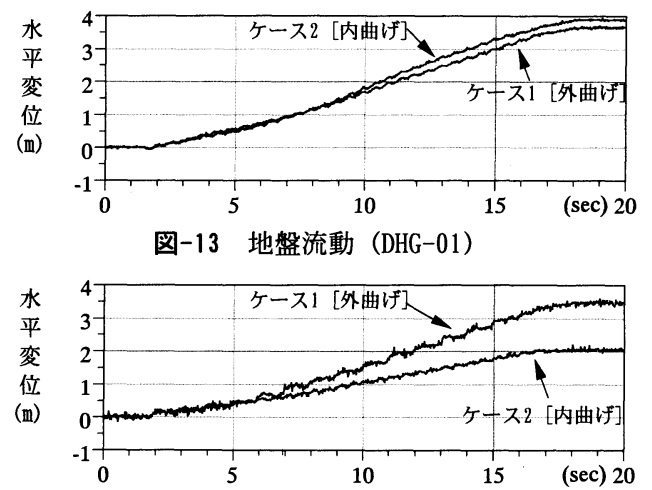

図-14 模型管端部の水平変位（DHP-01）

水圧比を示す. 護岸からやや離れた位置 [WP-13]では 1.0に達しており, 背後地盤の液状化が確認できるが, 護岸ごく近傍 [WP-32]では1.0まで上昇していない. これは, 地盤の流動に対して護岸の海側への変位が 先行することで護岸背後に開放面ができ，背後地盤 が膨張するためと考えられる. 図-12は，ケース1に おける護岸背面の壁面土圧 [EP-01]を示している. 護 岸上部に設置した [EP-01] では加振1波目にピークが あり，その後，土圧はほとんど作用していない，最 初のピークは護岸が慣性力によって内陸方向へ変位 するために生じる地盤圧縮応力であり, その後, 護 岸が先行して海側へ移動するため, 地盤との接触に よる土圧が低減したと考えられる.

\section{（3）模型管の変位と地盤流動量}

図-13に地盤水平変位 $[\mathrm{DHG}-01]$ を示す. 計測位置は, 上部非液状化層と下部夜状化層との境界で, 模型直

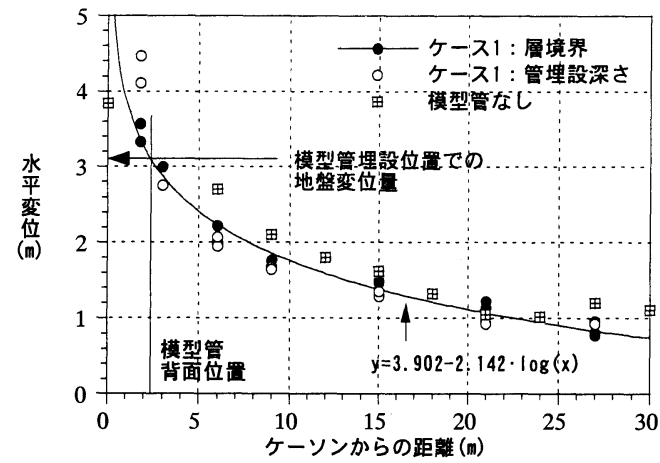

(a) ケース 1 [外曲げ]

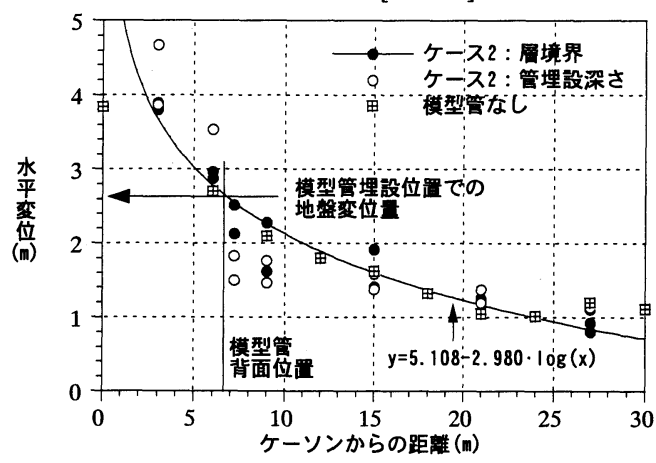

(b) ケース 2 [内曲げ]

図-15 模型管埋設位置での地盤変位量の推定

表-4 模型管の埋設位置での地盤流動量

\begin{tabular}{c|c|c}
\hline & $\begin{array}{c}\text { 護岸から管背 } \\
\text { 面までの距離 }\end{array}$ & $\begin{array}{c}\text { 管背面での } \\
\text { 地盤流動量 }\end{array}$ \\
\hline ケース 1(外曲げ) & $2.4 \mathrm{~m}$ & $3.09 \mathrm{~m}$ \\
\hline ケース 2(内曲げ) & $6.6 \mathrm{~m}$ & $2.67 \mathrm{~m}$ \\
\hline
\end{tabular}

管部の直下から $0.9 \mathrm{~m}$ (模型寸法 $3 \mathrm{~cm}$ ) 護岸側である (図 -6 参照). ケース $1 ， 2$ ともに水平変位量は $3 \mathrm{~m}$ 以上で ある. ただし, 各ケースともターゲットの設置が模 型管からやや護岸よりなので, 護岸背後地盤の崩壊 の影響を含んでいる. 図-14は模型管端部の水平変位 [DHP-01] を示している. 最終変位量はケース1[外曲 ゲ]が $3.8 \mathrm{~m}$ ，ケース $2[$ 内曲げ]が2. $2 \mathrm{~m}$ である.

後述の実験結果の検証では, 非線形シェル解析に よる埋設管の大変形解析手法を提案し, 実験結果の 検証を行っている. 提案手法は, 管周辺の地盤拘束 力と管埋設深さでの地盤変位量から管の変形を予測 する手法であり, 入力する地盤変位量は管が存在し ない状態での変位量を与えることが基本である. し かしながら, 実験では模型管の背後地盤が管の抵抗 を受けるため, 地盤変位量は管が無い場合よりも少 ないと予想される. 一方, 模型管を埋設していない 実験も実施しているが, 入力加速度の最大值や護岸 変位量がケース1およびケース2と一致しなかったた 

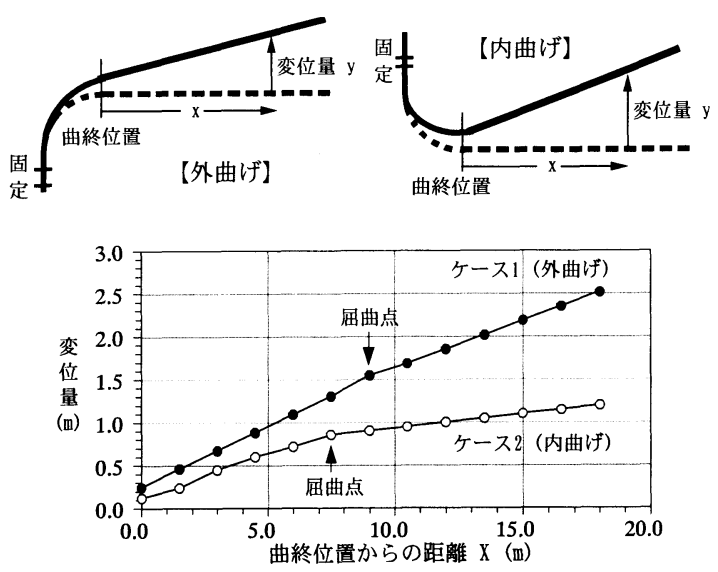

図-16 模型管（直管部）の変形

め, そこでの地盤変位量を管の変形解析に用いるの は適当でない，そこで, ケース1[外曲げ]およびケー ス 2 [内曲げ] の液状化層と非液状化層の境界での地 盤変位が，模型管の影響を比較的受けていないと判 断し，これを解析に用いることとした.

図-15 (a) および (b) に液状化層と非液状化層の境 界における地盤変位分布を示す．図-15(a)はケース 1 [外曲げ ]における層境界での地盤変位分布 $(\boldsymbol{O})$, 管 埋設深さでの地盤変位分布 $(\bigcirc)$, 模型管を埋設して いない実験ケースにおける管の埋設深さに相当する 位置での地盤変位分布 (田)を比較した．図-15(b)は ケース2[内曲げ]について同様の変位分布を示した.

図より，ケース1[外曲げ $]$, ケース2[内曲げ $]$ と に, 管埋設深さの地盤変位量 $(\bigcirc)$ は管埋設位置（ケ 一ス $1: X=2.4 \mathrm{~m}$ ，ケース $2: X=6.6 \mathrm{~m})$ の前後で差があ り，管の存在が影響していることがわかる. 一方, 層境界 (○)では管埋設位置の前後の変位量に大きな 差はなく, 模型管を埋設していないケースの地盤変 位（田）に比較的近い傾向と見ることが出来る. 以上 より，層境界での地盤変位に対する模型管の影響は 少ないと判断した. 図中に示す曲線はケース1, ケー ス2それぞれの層境界での地盤変位を対象とした回 帰分析の結果であり,この曲線から管埋設位置の地 盤変位量を算定した（表-4）.

\section{（4）模型管の変形}

図-16に側方流動による模型管の自由端側の変形 量を示す．図では，曲終位置（曲管部と直管部との 境界）からの距離を横軸, 側方流動による直管部の 水平変位量を縦軸としている．ここでの模型管の変 形量は, 管を地盤から掘り出して計測しているので, 地盤拘束力から開放されることにより弾性変形成分 が回復（スプリング・バック）した後の状態を示し

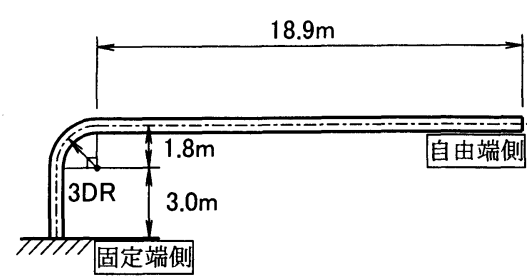

地盤変位方向

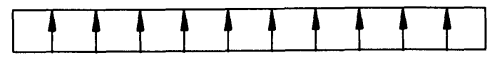

(a) 外曲げ

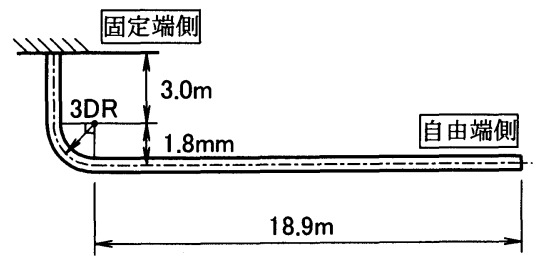

地盤変位方向

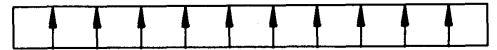

(b) 内曲げ

図-17 解析モデル

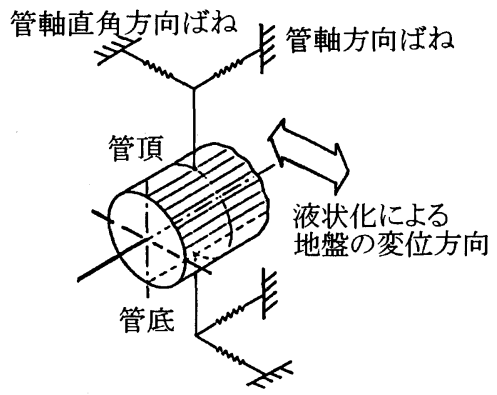

図-18 地盤ばねモデル

ている. ケース $1 ， 2$ ともに直管部の中央付近に屈曲 点が生じ, 曲管部とともに変形が集中している.

\section{5．遠心模型振動実験結果の検証}

埋設管の大変形解析手法の提案とその精度の検証 を目的として遠心模型振動実験の内曲げ, 外曲げの2 ケースについて非線形シェル解析の検討を行った.

\section{（1）解析条件}

非線形シェル解析の解析モデルを図-17に示す.モ デルの形状寸法，管径，管厚は実験に用いた模型管 の実測值を30倍した值としている．埋設管周辺地盤 をばね要素でモデル化し，地盤変位を強制変位量と してこのばね要素を介して埋設管に外力として作用 させる解析モデルとした. 解析に用いる地盤変位は, 図-15で示した遠心実験の地盤流動量の結果より, 埋 設管の影響が少ない液状化層と非液状化層の層境界 


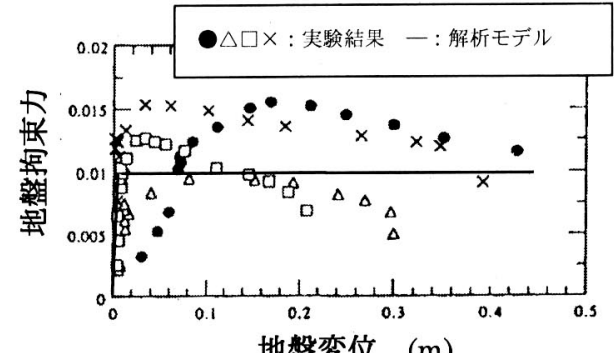

地盤変位 $(\mathrm{m})$

(a) 管軸方向

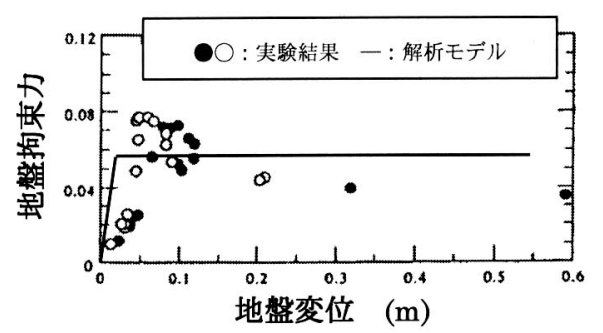

(b) 管軸直角方向

図-19 地盤ばねの特性 ${ }^{9)}$ （Shimamura らの図に加筆）

の変位を採用する．表-4に示したように地盤変位量 は外曲げで $3.09 \mathrm{~m}$, 内曲げで2. $67 \mathrm{~m}$ である. 地盤ばね 要素については埋設管の全節点に設定すると解析時 間が長くなり，現実的ではないため，高田ら ${ }^{21)}$ の研 究に基づき, 図-18に示すように地盤変位に対して直 角方向の管頂と管底の節点に代表させてばね要素を 設定した．この場合の解析時間は約 3 日を要し, 全節 点に地盤ばね要素を設定した解析に対して $1 / 3$ の所 要時間である.

Shimamura $ら^{99}$ は液状化層の上部の非液状化層に 土被り $60 \mathrm{~mm}(1.8 \mathrm{~m})$ で管径 $20 \mathrm{~mm}(600 \mathrm{~mm})$ の管を埋設 した模型を用いて, $30 \mathrm{~g}$ の重力場で遠心模型振動実 験を行い，地盤ばねの特性である地盤拘束力を測定 している，その実験結果を図-19に示す．液状化層が 存在しない地盤中に埋設した管の地盤拘束力の最大 值（管軸方向で0.019 0.025MPa，管軸直角方向で $0.46 \sim 0.47 \mathrm{MPa}$ ）と比較すると, 液状化による側方流 動が生じると非液状化層の地盤拘束力が低下すると 述べている. 図-19では地盤拘束力が最大值となった 後, 地盤変位が大きくなると地盤拘束力が低下して いるが，解析で岡性が低下するばね特性をモデル化 するのは困難なため, 本研究では地盤拘束力の最大 值と最小值の平均的な值（最大值の $75 \%$ の值）で一 定となるバイリニアモデル(著者らが図-19に実線で 加筆した）を地盤ばねの特性とし, 解析に使用した. 解析コードはABAQUS を使用し, 模型管のメッシュは 円周方向48分割とし, 1 積分点, 7 積分層数の 4 節 点非線形シェル要素を採用して解析を行った.
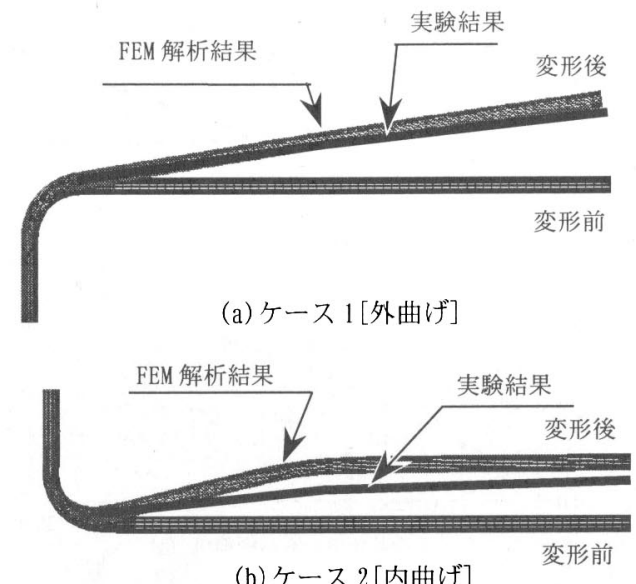

図-20 模型管の変形形状の比較

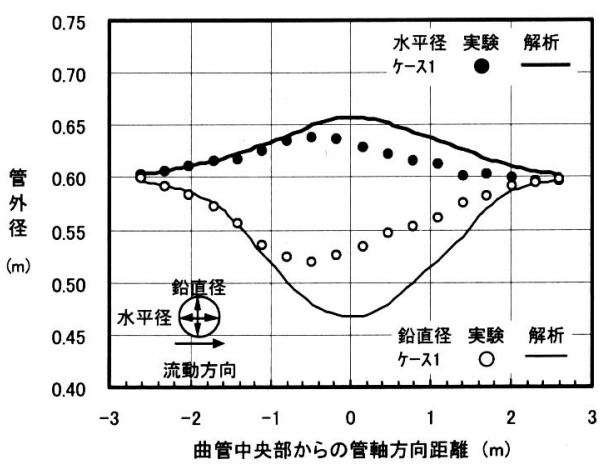

(a) ケース 1 [外曲げ]

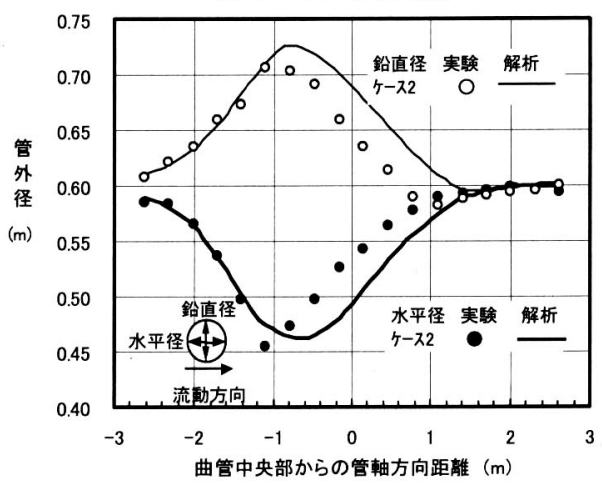

(b) ケース 2 [内曲げ $]$

図-21 管径の变化

\section{（2）解析結果と実験結果の比較}

実験土槽の地盤から掘り出した後の模型管の変形 形状について, 非線形シェル解析結果と遠心模型振 動実験結果を比較したものを図-20に示す. 掘り出し た後の模型管は地盤拘束力から解放されており弾性 変形成分が回復した後の状態のため, 非線形シェル 解析でも地盤ばねに変位を与えた後, 地盤ばねを取 
り除き弾性変形成分を回復させた変形量を図示して いる.これによると, 内曲げ, 外曲げとも解析の方 が若干大きく変形しているが概ね一致し，直管部の 屈曲など実験の傾向も再現されている. 図-21は変形 後の曲管部付近の管径を管軸方向分布として, 実験 と解析で比較している.これによると管の偏平状況 は, 解析結果が実験結果に比較して外曲げでは若干 大きくなっているが, 内曲げではほぼ同じとなって おり, 変形の傾向を再現できている.

以上の結果より，管材料の特性を持つシェル要素 によって埋設管をモデル化し，地盤の実験から得ら れた地盤ばね強さを設定したばね要素を介して, 地 盤変位を荷重として与える解析手法により FEM 解析 を行うことで, 埋設管の大変形挙動を精緻に解析で きることの妥当性が確認された. また, この解析手 法を用いて埋設配管系の詳細な大変形解析を行うこ とにより, 大規模地盤変状を考慮した埋設管の耐震 設計が可能であると考えられる.

\section{6. まとめ}

本研究では, 遠心模型振動実験により地震時にケ 一ソン護岸の背後に発生する地盤の側方流動と, そ れに伴う埋設管の変形の再現を試みた. その結果,

約 $4.0 \mathrm{~m}$ の側方流動が発生し, 埋設管端部では外曲げ $3.8 \mathrm{~m}$, 内曲げ $2.2 \mathrm{~m}$ の水平変位が生じた. このときの 液状化層と非液状化層の層境界での地盤変位量は, 外曲げ $3.09 \mathrm{~m}$, 内曲げ $2.67 \mathrm{~m}$ と推定された. また, 側 方流動に伴う地盤変位により模型管の変形は塑性領 域に達し, 直管部に生じた屈曲点, および曲管部に 変形が集中した. 曲管部の断面偏平は, 外曲げと内 曲げで方向が異なり, 外曲げでは上下方向, 内曲げ では水平方向に潰れた形状となった.

次にシェル要素による数值解析手法により実験結 果をシミュレートし, 手法の妥当性を確認した. 遠 心模型実験をモデル化した非線形シェル解析を行っ た結果, 実験結果を良好に再現できた。これにより, 埋設管をシェル要素で, 地盤をばね要素でモデル化 した, 埋設管の地盤変位に対する大変形解析手法の 妥当性が検証できた.

本研究で示した非線形地盤ばね要素を用いた非線 形シェル解析手法は, 液状化による側方流動のよう な大規模な地盤変状を受ける埋設管の耐震設計手法 としても, 最も適した解析手法であると考えられる. また,この解析手法を用いた液状化側方流動を受け る埋設管の検討結果をもとに, 計算式による簡易設 計手法も検討している.
謝辞：本研究における実験結果は（社）日本ガス協 会が経済産業省資源エネルギー庁からの委託により， 平成8年度から調査研究を進めてきた「ガス導管液状 化対策調査」における平成 12 年度の成果の一部であ る. 経済産業省をはじめとする関係各位,「ガス導管 液状化対策調查研究特別委員会 (委員長 : 片山恒雄 防災科学技術研究所理事長)」の各委員に感謝の意を 表する. 特に第二小委員会の鈴木崇伸委員，小池武 委員, 小口惠武委員, 北野哲司委員らには貴重な御 助言を頂いた.ここに感謝の意を表する.

\section{参考文献}

1）高田至郎, 前田俊宏, 辻野洋慶 : 地中埋設物の被害 と特徴, 阪神・淡路大震災に関する学術講演会論文 集, pp. 283-288, 1996.

2）鈴木崇伸, 清水善久, 小金丸健一, 安藤広和：埋設 管被害と地震動・地盤との関連について, 第 2 回阪 神・淡路大震災に関する学術講演会論文集, pp. 163-170, 1997.1.

3） 高田至郎 : ライフライン地震工学, pp. 7-26, 1991.

4）濱田政則, 安田進, 磯山龍二, 恵本克利 : 液状化に よる地盤の永久変形の測定と考察, 土木学会論文集, №. 376/III-56, pp. 211-220, 1986.

5) Ishihara, K. :Liquefaction and flow failure during Earthquakes, The 33rd Rankin Lecture of the British Geotechnical Society, Geotechnique, Vol.43, No. 3, pp349-415, 1993.

6）社団法人日本道路協会 : 道路橋示方書 - 同解説, V 耐震設計編, pp. 85-90, 平成8年12月.

7）鉄道構造物等設計標準 - 同解説 而震設計, 平成 11 年 10 月.

8）高圧ガス保安協会 : 高圧ガス設備等耐震設計指針, レベル2耐震性能評価 解説編, pp. 197-223, 平成12 年7月.

9) Shimamura, K., Hamada, M., Yasuda, S., Oht omo, K., Fuji ta, Y., Kojima, S. and Taji, Y. : Load on pipes buried in a non-liquefaction layer due to liquefaction induced ground displacement, 12 th World Conference on Earthquake Engineering, No. 0492, 2000.

10）佐藤正義 : 遠心力場におけるケーソン岸壁および杭 基礎の液状化被害に関する再現実験, 土木学会論文 集 No. 582/III-41, pp. 295-304, 1997. 12.

11）濱田政則, 若松加寿江 : 液状化による地盤の側方流 動のメカニズム（その 2$)$ 模型地盤と実地盤間の相 似則と地盤変位量の予測, 地震時の地盤・土構造物 の流動性と永久変形に関するシンポジウム発表論文 集, pp. 309-312, 1998. 
12）國生剛治, 故島哲朗，中野孝威，野中のぞみ，渡邊 一洋 : 液状化地盤の流動メカニズムに与える水膜現 象（WFE）の影響に関する模型実験, 地震時の地盤・ 土構造物の流動性と永久変形に関するシンポジウム 発表論文集, pp. 313-316，1998.

13）濱田政則，島村一訓，柳瀬和俊，中村正樹，田中淳 寛 : 液状化土の流動特性に関する研究, 第2回構造物 の破壊過程解明に基づく地震防災性向上に関するシ ンポジウム論文集, pp. 261-266, 2001.

14）大友敬三 : 地中洞道と杭に作用する外力について, 地震時の地盤・土構造物の流動性と永久変形に関す るシンポジウム発表論文集, pp. 369-374, 1998.

15）濱田政則, 飯田康史, 志摩美裕貴, 山田隆一：側方 流動地盤が杭に及ぼす外力に関する模型実験と数値 解析, 第 25 回地震工学研究発表会論文講演集, pp. 373-376, 1999.

16）小笠原政文, 五瀬伸吾, 佐藤正義, 宮田和 : 側方流 動により基礎構造物に作用する流動圧の遠心振動実 験, 土構造物の流動性と永久変形に関するシンポジ ウム発表論文集, pp. 381-384, 1998.

17）田透揮司良 : 地震時地盤変状を受ける地中管路の耐 震性評価と設計法に関する基礎的研究, 神戸大学提 出学位論文, pp. 147-166, 1989.

18）高田至郎, 山部泰男 : 沈下土槽による埋設管路の大変 形挙動実験とその解析, 土木学会論文報告集, №. 323, pp. 55-65, 1982.7.

19）高田至郎, 田邊揮司良, 狭間祐二, 入岡博明 : マン ホール際管路の沈下挙動実験と対策管路の開発, 土 木学会論文報告集， No. 374/I-6， pp. 575-582， 1986. 10.

20）（社）日本ガス協会：ガス導管耐震設計指針， pp. 284-285, 1982.

21）高田至郎, 小川安雄, 吉崎浩司, 北野哲司, 岡村一
男 : 液状化側方流動を受ける埋設管の大変形挙動に 関するハイブリッド弾塑性解析手法, 第10回日本地 震工学シンポジウム論文集, pp.61-66, 1998.

22) Yoshizaki, K. and Oguchi, N. :Estimation of the deformation behavior of elbows for an earthquake resistant design, 11th World Conference on Earthquake Engineering, No. 1783, 1996.

23) Miki, C., Kobayashi, T., Oguchi, N., Uchida, T., Suganuma, A. and Katoh, A. : Deformation and fracture properties of steel pipe bend with internal pressure subjected to in-plane bending, 12 th World Conference on Earthquake Engineering, No. $1814,2000$.

24) Hibbitt, Karlsson and Sorensen, Inc. : ABAQUS / Standard User's Manual, ver5. 8, 1998.

25) Yoshizaki, K., D. 0'ROURKE T., and Hamada, M. :Large deformation behavior of buried pipelines with low-angle elbows subjected to permanent ground deformation, J. Struct. Mech. Earthquake Eng., JSCE, No.675/I-55, pp. 41-52, 2001. 4.

26）太田孝二, 中川知和, 中村聖三, 水谷慎吾, 小林洋 一，野中哲也：鋼製橋脚の耐震設計に対する構造解 析ソフトウエアの適用性, 橋梁と基礎, Vol. 31, №. 12, pp. 33-39, 1997.

27）井合進, 一井康二, 森田年一, 佐藤幸博 : 既往の地 震事例に見られる液状化時の護岸変形量について, 第2回阪神・淡路大震災に関する学術講演会論文集, pp. 259-264, 1997.

28）財団法人沿岸開発技術研究センター : 埋立地の液状 化対策ハンドブック, pp.116-117，1997.

\title{
LARGE DEFORMATION OF BURIED PIPELINE DUE TO GROUND DISPLACEMENT CAUSED BY LATERAL FLOW
}

\author{
Kiyoshi SATO, Masaaki MATSUMOTO, Shiro TAKADA and Yasuo OGAWA
}

\footnotetext{
A dynamic centrifuge test and FEM analysis were carried out to investigate a seismic behavior of buried pipeline due to lateral flows caused by ground liquefaction. The model of the centrifuge test, which was performed under the centrifugal acceleration of $30 \mathrm{~g}$, consisted of a caisson type quay wall, upper unliquefable, lower liquefable layer and high-pressure gas tube with the outer diameter of $600 \mathrm{~mm}$ in prototype scale including a 90 degree bent part. Lateral flow induced by the deformation of the quay wall made the model pipe a large deformation up to plastic strain level. Furthermore, the applicability of analysis by FEM shell model was verified to simulate the large deformation of pipe model.
} 